\title{
RARE EARTH ELEMENTS IN MIDDLE PRECAMBRIAN VOLCANIC ROCKS OF FINLAND, WITH A DISCUSSION OF THE ORIGIN OF THE ROCKS
}

\author{
T. Koljonen and R. J. Rosenberg
}

\begin{abstract}
Koljonen, T. and Rosenberg, R. J. 1975: Rare Earth Elements in Middle Precambrian Volcanic Rocks of Finland, with a Discussion of the Origin of the Rocks. Bull. Geol. Soc. Finland 47, 127-138.
\end{abstract}

The contents of rare earth elements (REE) have been determined in five Svecofennian metamorphosed volcanic rocks and are compared with those found in the Karelian zone and Recent tholeiites. In the Svecofennian zone, REE contents in low silica volcanic rocks are like those in the calc-alkalic series and in continental tholeiites, whereas in the Karelian zone they are like those in island arc tholeiites. It is argued that in the Karelian zone, where magmatism initiated, tholeiitic basalts originated in the upper mantle; as shown in normalized form, the light REE are depleted, reflecting the distribution pattern found, for example, in rocks of pyrrolite composition. As orogeny advanced, more and more crustal material - basement and geosynclinal sediments - was recycled and the REE distribution pattern changed to that found in the synorogenic calc - alkalic rocks $(1.8-1.95 \mathrm{Ga})$, reflecting the REE pattern present in sediments.

The chemical composition of the magmatic rock series formed during Svecokarelian folding is quite like that observed in island arc systems.

Tapio Koljonen, Department of Geology and Mineralogy, University of Helsinki, SF-00170 Helsinki 17, Finland.

Rolf J. Rosenberg, Reactor Laboratory, Technical Research Centre of Finland, SF02150 Espoo 15, Finland.

\section{Introduction}

On the basis of REE distribution, tholeiitic basalts can be classified as of the oceanic or island arc types or the continental type (Frey et al. 1968; Herrmann 1968, 1970; Jakeš \& Gill 1970; Nakamura \& Masuda 1971; Schilling \& Winchester 1969). On the whole, the total REE content in tholeiites is lower than in alkali- and silica-rich rocks and higher than in olivine- and pyroxenerich mafic rocks. Oceanic and island arc tholeiites contain less REE than continental tholeiites or gabbroic calc-alkalic rocks, and the $\mathrm{La} / \mathrm{Yb}$ ratio is about unity, whereas for the latter it is about ten ( $c f$. Jakeš \& Gill 1970). The REE pattern found in oceanic types is attributed to differentiation within the upper mantle - e.g., in the low velocity zone - the chemical composition of which 
is similar to that of chondrites (e.g. Green 1970; Green \& Ringwood 1967; Masuda \& Matsui1966). In Precambrian and Recent volcanic rocks the trace as well as the major element compositions are the same. The content and distribution patterns of elements such as REE, $\mathrm{U}$, and Th, which are unable to substitute to any appreciable extent in the major minerals of the upper mantle (olivine, aluminous pyroxene, etc.), have not changed in basalts with time. Yet, olivine-pyroxene rock itself, which is similar to chondrites, cannot give rise to magmas having constant composition through all geologic time. To explain the constant chemical composition of those parts of the Earth where magmas have formed, Jahn, Shih, and Murthy (1974), among others, have proposed that either the trace elements have been repeatedly and fully recycled within a restricted and closed system of the crust and the upper mantle during the last three gigayears (recycled mantle), or the trace elements have been replenished from the lower part of the mantle (replenished mantle).

Since REE as a group offer much petrogenetic information, we have studied their content and distribution patterns in some Middle Precambrian metamorphic volcanic rocks found in Finland.

\section{Experimental and the normalization of REE contents}

REE have been determined by instrumental activation analysis as described earlier (Rosenberg \& Wiik 1971; Rosenberg 1972). Major elements have been analyzed by the conventinal wet method and alkalis by atomic absorption spectrometry.

REE contents are presented normalized against chondrites, as proposed by Masuda and Coryell; in the figures they are normalized against Leedey (L/6) chondrite (Masuda et al. 1973; Koljonen \& Rosenberg 1974). The total REE contents in tables have been calculated from the graphs.

\section{General geology}

The regional distribution of volcanogenic rocks in Finland is displayed in Fig. 1. Volcanic rocks and their plutonic differentiates belonging to the Svecokarelian folding are grouped with the Karelian and Svecofennian rocks ( $c f$. Eskola 1963).

The Karelian metasediments belong to epicontinental facies and are deposited along the northeastern boundary of the Svecokarelian fold belt in the neighborhood of an old craton. In the Karelian zone, basic extrusives and intrusives are mostly found in Jatulian sedimentary rocks, which have deposited on Prekarelian gneisses. Basic volcanic rocks usually occur in quartzites, but they are also found in shales and dolomites, and in places they cut the basement. The texture is often ophitic and, in the largest dykes, gabbroid. Most of them represent low-temperature mineral facies - greenschist, or the epidoteamphibolite facies, and near granites also amphibolite facies. Albite-rich spilitic rocks are also typical of the Karelian zone ( $c f$. Piirainen \& Rouhunkoski 1974). Basic volcanic rocks are not met with in the topmost, the Kalevian medasediments of geosynclinal facies ( $c f$. also Eskola 1925; Ga ál \& Rauhamäki 1971; Härme 1949; Laajoki 1973; Meriläinen 1961; Mikkola 1949; Nykänen 1971; Piispanen 1972; Väyrynen 1928).

The Svecofennian metasediments belong mostly to geosynclinal facies. Situated in southern and southwestern Finland, they form an arc in W-E and SE-NW direction, south of the silica-rich plutonic rocks of central Finland. These plutonic rocks separate the medasediments of the Karelian and Svecofennian zones. The Svecofennian supracrustal sequence has sedimented in a basin whose base in unknown (Simonen 1953). The metasediments from bottom to top are phyllites, graywackes, and graded shales. Lying over them are arkoses, graywackes, and conglomerates, with interbeds of acid and basic volcanic rocks, and the basic volcanic rocks overlie the sediments. South of the schist belt, basic and 


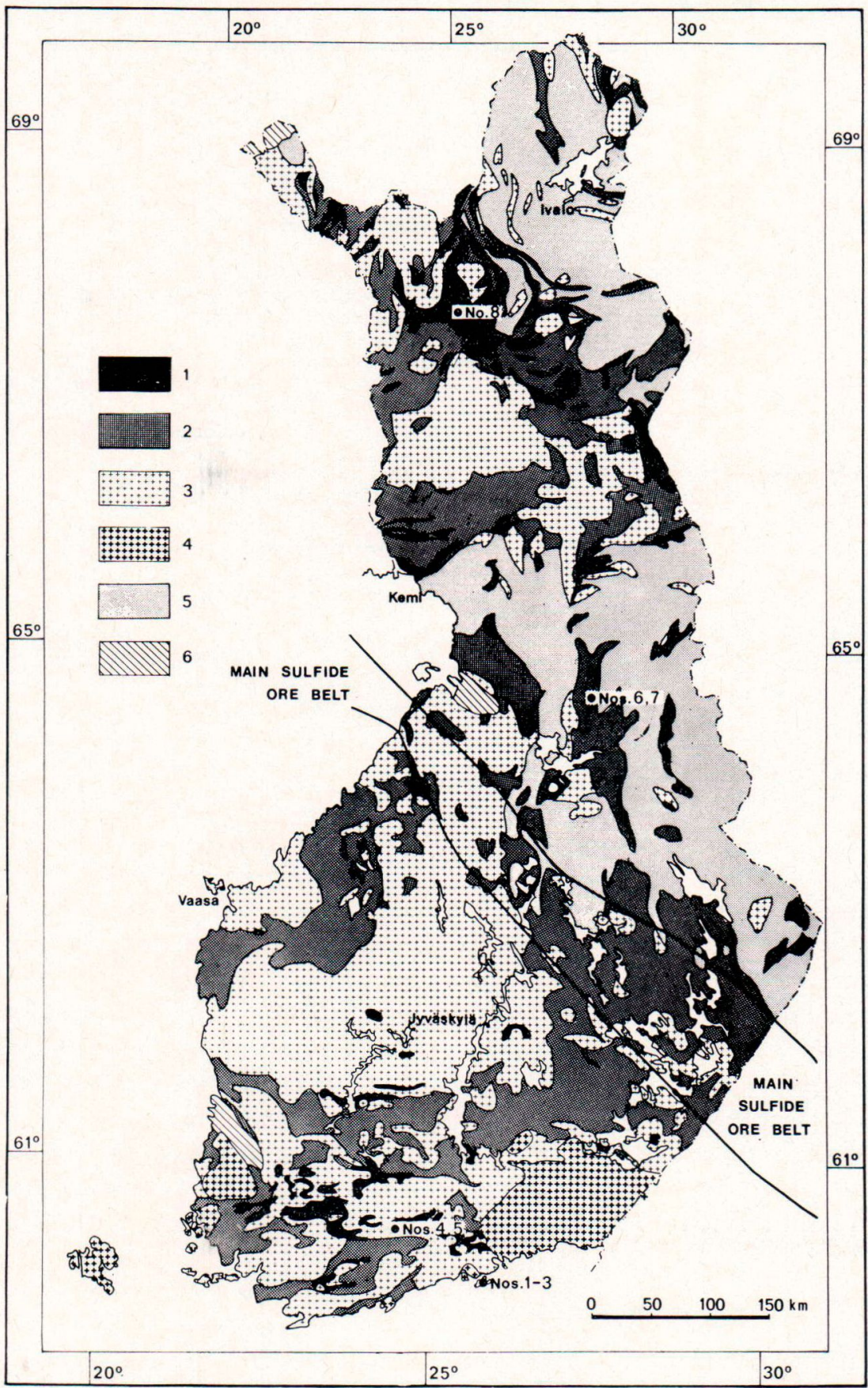

Fig. 1. Sites of samples studied presented on a generalized geological map of Finland (Simonen 1960 a). 1. Volcanic rocks; 2. schists (including quartzite); 3. silicic plutonic rocks; 4. rapakivi intrusions; 5. Presvecokarelian basement (schist, paragneiss, granulite, orthogneiss); 6 . Jotnian and Caledonian sedimentary rocks. 
TABLE 1

Petrography of investigated Svecofennian samples

\begin{abstract}
No. Rock type
2 Uralite porphyry (pillow lava)
\end{abstract}

Texture

1 Metabasalt (gabbroid) Blastoporphyritic with granoblastic and hypidiomorphic features

3 Metavolcanite

4 Uralite gabbro

5 Metavolcanite
Hypidiomorphic

Somewhat foliated. Matrix is granoblastic and plagioclase is cumulophyric

Blastoporphyritic, fine-grained

Stratified, fine-grained
Mineral assemblage

Plagioclase $\left(\mathrm{An}_{55-60}\right)$, hornblende, hypersthene, augite, biotite; accessory magnetite, serpentine

Plagioclase $\left(\mathrm{An}_{50}\right)$, hornblende; accessory sphene, sericite, apatite, zircon, calcite, magnetite

Hornblende, plagioclase $\left(\mathrm{An}_{30-40}\right)$; accessory quartz, biotite, chlorite, epidote

Plagioclase $\left(\mathrm{An}_{55-60}\right)$, horn- Hyvinkää, Kytäjä blende, uralite, augite, biotite; accessory apatite, tremolite, chlorite, magnetite, quartz, calcite

Plagioclase $\left(\mathrm{An}_{10-15}\right)$, chlorite, quartz, potassium feldspar; accessory magnetite, epidote, calcite, apatite, zircon, biotite
Location

Porvoo, Suur-Pellinki, Nyttisholmen

Porvoo, Suur-Pellinki

Porvoo, Suur-Pellinki, Ednäs

Hyvinkää, Kytäjä acid (leptite) volcanogenic intercalations in schists are found. The metamorphic grade in the Svecofennian zone is higher than in the Karelian zone and the rocks are mostly of amphibolite and granulite facies. Plutonic rocks cut the schists, and migmatitic rocks are very common in southern Finland. Rapakivigranites $(1.6 \mathrm{Ga})$ form a separate group, which became emplaced after the main phase of Svecokarelian folding ( $c f$. also Sederholm 1897, 1907, 1923, 1926, 1934; Seitsaari 1951; Simonen 1960 b; Tuominen 1958, 1966).

\section{Geology of the studied areas}

Petrography, and major element and REE contents of the Svecofennian volcanogenic rocks studied are displayed in Tables 1, 3, and 4.

The volcanic rocks in Pellinki (Nos. 1-3) form a uniform area where primary structures are well preserved (Laitala 1973). They are mostly pyroclastic and are formed from tuffs and agglomerates which later, in folding, underwent metamorphism. Basic tuffs predominate but also intermediate and acid ones are found. With the pyroclastic rocks there are also metamorphosed lava beds, which are mostly basic uralite porphyries and contain variants resembling plutonic rocks. In a few places, lavas rich in silica are also found ( $c f$. also Laitala 1964, 1965; Sederholm 1923, 1926).

In Hyvinkää (Nos. 4 and 5) basic volcanic rocks surround a belt of plutonic rocks (Härme 1953, 1954). Basic and intermediate banded tuffites are common and lenses of agglomerate occur on both sides of the gabbro. The banded volcanic rocks are, in part, pyroclastic and in places are sedimentary in character with intercalations of mica schist. The volcanic rocks are 
TABLE 2

Rocks and references to the normalized REE analyses displayed in Figs. 2 and 3

No. Rock type

6 Basic tuffite

7 Metadiabase

8 Greenschist

9 Oceanic tholeiites (average of 11 tholeiites and olivine tholeiites)

10 Continental tholeiites (average of 163 samples)

11 Deccan traps (average Mahabaleshwar region, India of 10 tholeiites)

12 Continental tholeiite Columbia Plateau, USA

13 Precambrian shales (average of 36 samples)

Average of Svecofennian volcanic rocks (TABLE 1, Nos. $1-5$ )

Synorogenic Precambrian granites (average of 5 samples)

Average of volcanic Finland

Finland

s and synoro-
28

18

23

Kohala Mt., Hawaii, Mid-

Atlantic Ridge, East

Pacific Rise

Siberian Platform, Noril'sk region, USSR

Finland

196

137

83

82

106

182

108

76
$\mathrm{La} / \mathrm{Yb}$

References genic granites (Nos. $14-15)$ penetrated by dykes of gabbro, diorite, granodiorite, and microcline granite (Simonen 1948, 1960 b). Gabbro is accompanied by fine-grained marginal varieties that grade into the volcanic rocks, the latter representing an extrusion of early orogenic phase, the gabbros being intrusives. It seems that the other plutonic rocks, ex-cluding microcline granites are comagmatic products of differentiation. The granites, which penetrate all rocks, belong to the late-kinematic phase (cf. also Tenhola 1971).

\section{REE distribution in the investigated areas}

Compared with chondrites, the light REE are enriched in both the rock series investigated (Figs. 2 a, b), and the distribution patterns resemble those found in continental tholeiites (Table 2, Fig. 2 d, Nos. 10-12). In the pillow lava (Table 1, No. 2) major element content (e.g. sodium) has altered after deposition, but the REE content has not changed either through weathering or by metamorphism. REE do not 


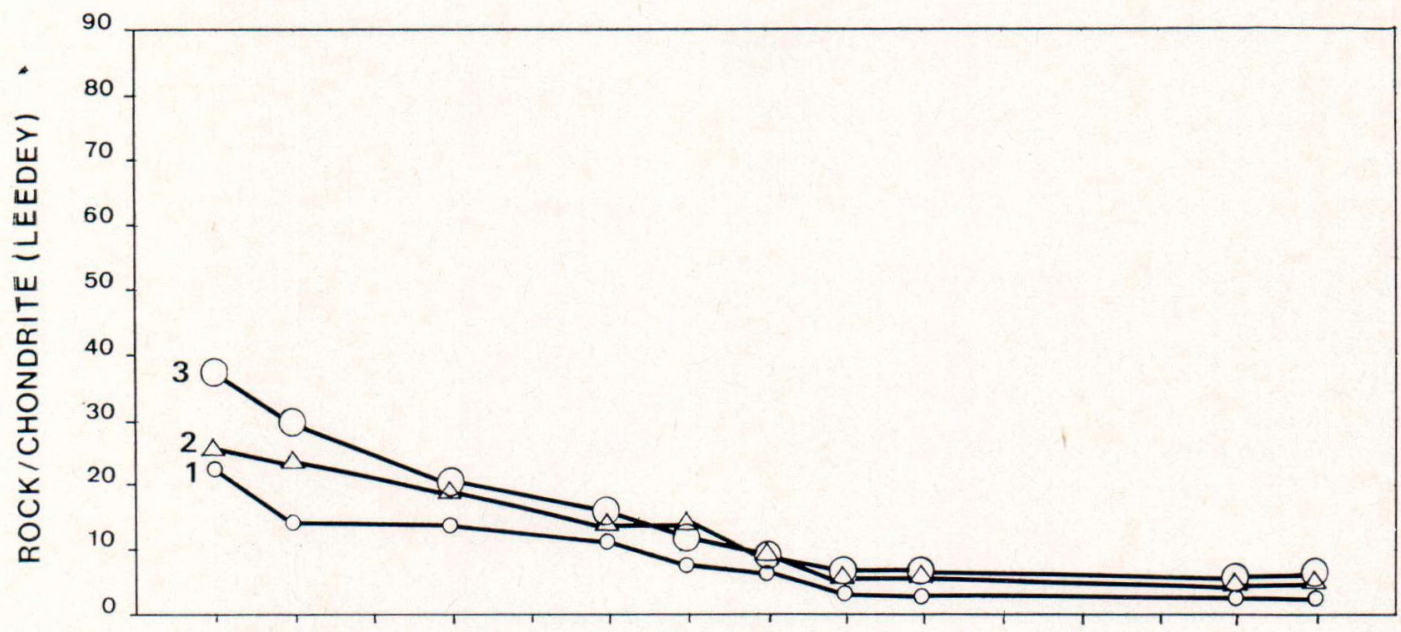

La Ce Pr Nd Pm Sm Eu Gd Tb Dy Ho Er Tm Yb Lu

Fig. 2. REE contents normalized against chondrite (Leedey, Masuda et al. 1973). The numbers on the graphs indicate the analyses shown in Tables 1 and 2.

a) Volcanic rocks from Pellinki (Nos. 1-3). Svecofennian zone.

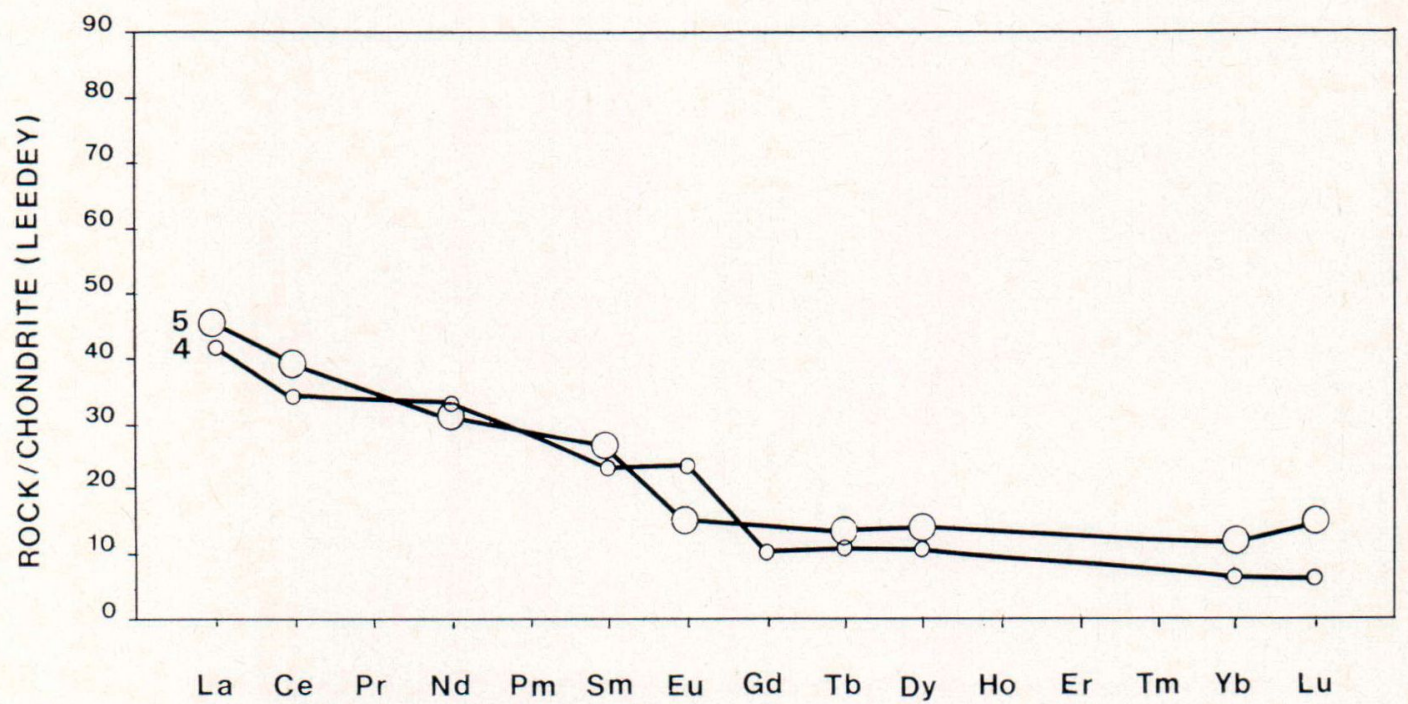

b) Gabbro (No. 4) and metavolcanite (No. 5) from Hyvinkää. Svecofennian zone.

migrate before high metamorphic conditions are established (Koljonen \& Rosenberg 1974).

Most REE are found in silica-rich differentiates. Similar distribution patterns in the two groups indicate that each of them forms a co-magmatic series, and the gabbro (No. 4) in Hyvin- kää has differentiated from magma which earlier brought about the adjacent volcanic rocks. The $\mathrm{Eu}$ anomaly is positive because in gabbro $\mathrm{Eu}$ is incorporated into plagioclase in place of $\mathrm{Ca}$, and through crystal accumulation of plagioclase is concentrated into the gabbro fraction. The 


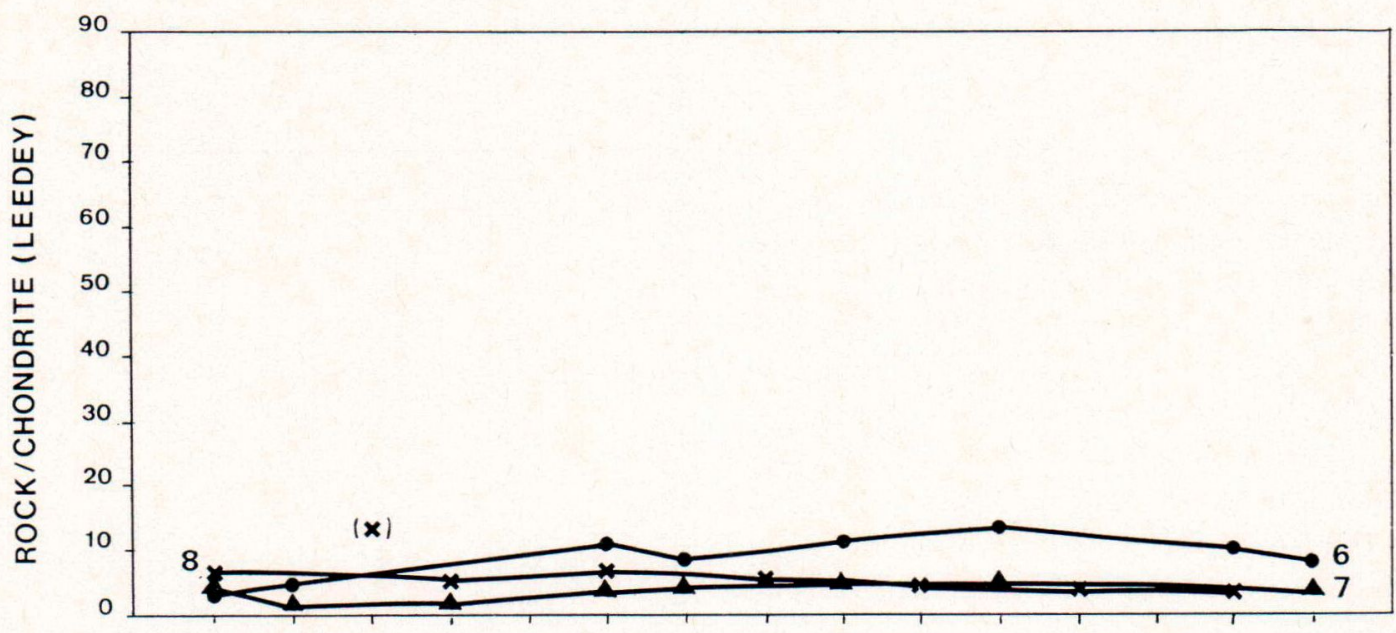

La Ce Pr Nd Pm Sm Eu Gd Tb Dy Ho Er Tm Yb Lu

c) Basic tuffite (No. 6), metadiabase (No. 7), and greenschist (No. 8). Karelian zone.

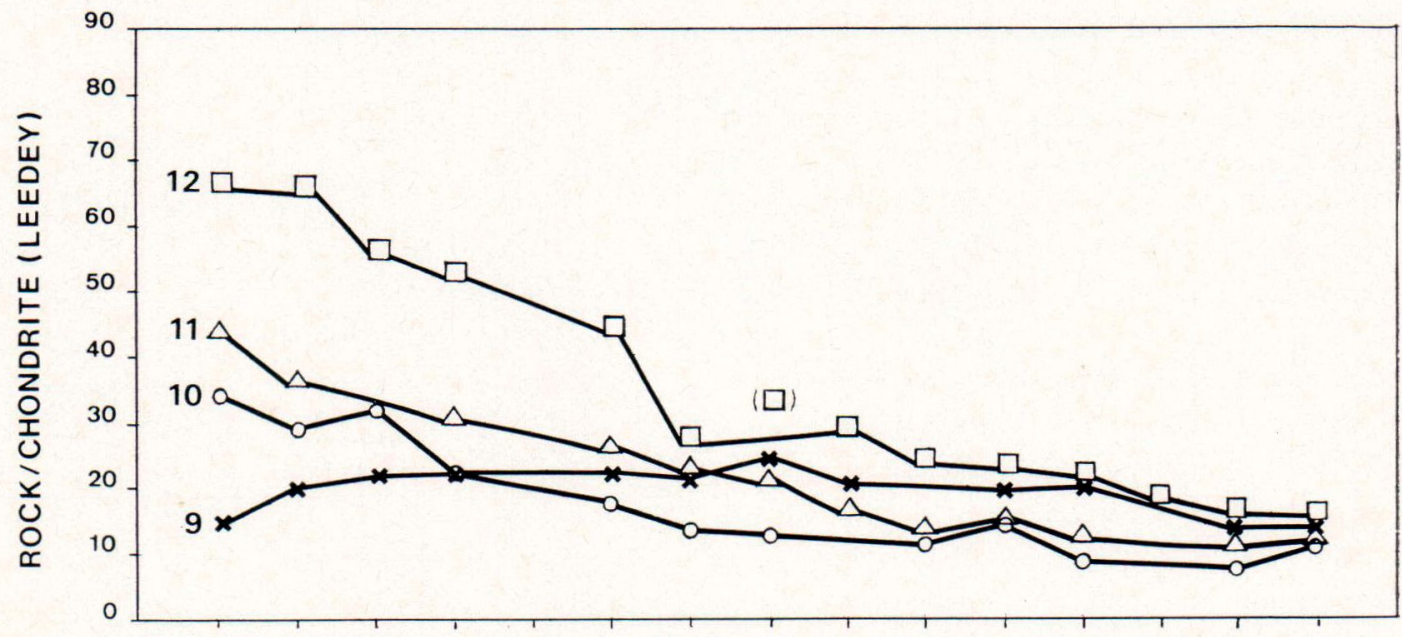

La Ce Pr Nd Pm Sm Eu Gd Tb Dy Ho Er Tm Yb Lu

d) Oceanic tholeiites (No. 9), continental tholeiites from Siberia (No. 10), Deccan traps (No. 11), and a continental tholeiite from Columbia Plateau (No. 12).

remaining melt, on the other hand, was enriched in silica during the process and is depleted of Eu. The enrichment of $\mathrm{Eu}$ in the early differentiates is, to a lesser degree, also observed in the Pellinki area (Nos. 2 and 3).

The REE distribution patterns are quite simi- lar, demonstrating that, although total contents differ, the magmas have originated in the same manner during the Svecokarelian folding, and that the volcanic rocks in southern Finland are genetically related to the synorogenic calc alkalic plutonic rocks. 


\section{Discussion}

The contents and distribution patterns found in Precambrian volcanic rocks in Finland are quite like those of the Recent period, and the REE distribution in upper mantle and crust seems to be formed through the recycling of the elements in a closed system in the Earth. Although the mineralogy and chemistry are still under study, on the basis mostly of REE distribution there would seem to be a fundamental difference between Karelian and Svecofennian volcanic rocks, reflecting their different origins. This has also a great influence on the chemical composition of ores formed (e.g. oxide or sulfide). In the Karelian sequence (Table 2, Fig. 2 c) the REE are like those in island arc (or abyssal) tholeiites (Table 2, Fig. 2 d, No. 9), and in the Svecofennian sequence like those in calc alkalic rocks. The boundary between these types is not sharp because areas where magmas are formed shift during orogeny, and silica-rich synorogenic plutonic rocks also are found in the Karelian zone. Also possible is the mixing of magmas formed at different depths, and the lateral separation of magmas is dependent on the dip of the active fault planes (Benioff seismic zone).

In the most prominent shear zone in Finland (Kahma 1974; Mikkola \& Niini 1968; Tuominen et al. 1973), which seems to separate calc alkalic and tholeiitic magma series, is situated the main sulfide ore belt (Fig. 1). Probably sulfides mobilized and migrated from metasediments to this belt and accumulated before the orogenic plutonic rocks were emplaced (Koljonen 1974, 1975). Also it is possible, and even probable, that early volcanism introduced elements found in ores to the sediments in the first place ( $c f$. Piirainen 1974). The high content of selenium and low S/Se ratio support this hypothesis because $\mathrm{Se}$ is a common element in high-temperature volcanic emanations.

Since REE contents and distribution patterns in the Karelian volcanic rocks (Fig. 2 c) are
TABLE 3

Chemical compositions and norms of Svecofennian volcanic rocks.

The numbers indicate samples in TABLE 1

\begin{tabular}{|c|c|c|c|c|c|}
\hline No. & 1 & 2 & 3 & 4 & 5 \\
\hline $\mathrm{SiO}_{2} \ldots$ & 46.96 & 50.44 & 57.43 & 50.09 & 61.40 \\
\hline $\mathrm{Al}_{2} \mathrm{O}_{3}$ & 17.28 & 17.88 & 15.64 & 15.68 & 13.91 \\
\hline $\mathrm{Fe}_{2} \mathrm{O}_{3}$ & 5.98 & 4.27 & 4.03 & 4.64 & 4.95 \\
\hline $\mathrm{FeO} \ldots$ & 6.95 & 6.64 & 5.31 & 6.34 & 2.22 \\
\hline $\mathrm{MnO}$ & 0.16 & 0.09 & 0.06 & 0.16 & 0.08 \\
\hline $\mathrm{MgO}$. & 7.30 & 2.91 & 3.83 & 6.31 & 2.21 \\
\hline $\mathrm{CaO}$. & 10.12 & 10.40 & 7.43 & 9.76 & 6.49 \\
\hline $\mathrm{Na}_{2} \mathrm{O}$ & 3.60 & 4.33 & 2.62 & 3.46 & 2.26 \\
\hline $\mathrm{K}_{2} \mathrm{O} \ldots$ & 0.51 & 0.83 & 1.80 & 1.03 & 4.85 \\
\hline $\mathrm{H}_{2} \mathrm{O}+$ & 0.67 & 0.26 & 0.91 & 0.49 & 0.92 \\
\hline $\mathrm{H}_{2} \mathrm{O}-$ & 0.16 & 0.08 & 0.02 & 0.11 & 0.20 \\
\hline $\mathrm{TiO}_{2}$ & 0.69 & 1.03 & 0.95 & 1.53 & 0.80 \\
\hline $\mathrm{P}_{2} \mathrm{O}_{5}$. & 0.23 & 0.32 & 0.27 & 0.35 & 0.18 \\
\hline Total & 100.61 & 99.48 & 100.30 & 99.95 & 100.47 \\
\hline \multicolumn{6}{|c|}{ CIPW norms } \\
\hline $\mathrm{qz} \ldots$ & - & - & 14.22 & - & 16.79 \\
\hline or $\ldots$ & 3.01 & 4.90 & 10.64 & 6.09 & 28.66 \\
\hline$a b \quad \ldots$ & 26.27 & 35.21 & 22.17 & 29.28 & 19.12 \\
\hline$n \ldots$ & 29.48 & 26.90 & 25.60 & 24.21 & 13.49 \\
\hline$\ldots$ & 2.27 & 0.78 & - & - & - \\
\hline i... & 15.45 & 18.70 & 7.71 & 17.59 & 11.87 \\
\hline wo ... & - & - & - & - & 0.95 \\
\hline hy $\ldots$ & - & - & 10.77 & 8.88 & - \\
\hline ol ... & 12.78 & 3.77 & - & 2.85 & - \\
\hline $\mathrm{mt}$. & 8.67 & 6.19 & 5.84 & 6.73 & 5.09 \\
\hline$\ldots$ & 1.31 & 1.96 & 1.80 & 2.91 & 1.52 \\
\hline he $\ldots$ & - & - & - & - & 1.44 \\
\hline ap $\ldots$ & 0.53 & 0.74 & 0.63 & 0.81 & 0.42 \\
\hline $\mathrm{H}_{2} \mathrm{O} \ldots$ & 0.83 & 0.34 & 0.93 & 0.60 & 1.12 \\
\hline
\end{tabular}

TABle 4

REE contents of Svecofennian volcanic rocks.

The numbers indicate samples in TABLE 1

The values in parentheses are estimates

\begin{tabular}{|c|c|c|c|c|c|c|}
\hline No. & 1 & 2 & 3 & 4 & 5 & Leedey \\
\hline La... & 8.6 & 10 & 14.4 & 15.7 & 17 & 0.378 \\
\hline $\mathrm{Ce} . .$. & 15 & 23 & 29 & 33 & 38 & 0.976 \\
\hline $\operatorname{Pr} \ldots$ & - & - & - & - & - & $(0.138)$ \\
\hline $\mathrm{Nd} \ldots$ & 11 & 14 & 14.5 & 23 & 22 & $0.716^{\prime}$ \\
\hline $\mathrm{Sm} .$. & 2.8 & 3.4 & 3.8 & 5.4 & 6.1 & 0.230 \\
\hline $\mathrm{Eu} . .$. & 0.70 & 1.10 & 1.07 & 2.02 & 1.25 & 0.0866 \\
\hline Gd... & 2.5 & 2.7 & - & 3.1 & - & 0.311 \\
\hline $\mathrm{Tb} \ldots$ & 0.31 & 0.40 & 0.45 & 0.58 & 0.78 & $(0.0568)$ \\
\hline Dy ... & 1.4 & 2.1 & 3.1 & 4.1 & 5.6 & 0.390 \\
\hline Ho ... & - & - & - & - & - & $(0.0868)$ \\
\hline Er... & - & - & - & - & - & 0.255 \\
\hline $\mathrm{Tm} \ldots$ & - & - & - & - & - & $(0.0399)$ \\
\hline $\mathrm{Yb} \ldots$ & 1.0 & 1.22 & 1.48 & 1.82 & 3.0 & 0.249 \\
\hline $\mathrm{Lu} \ldots$ & 0.21 & 0.22 & 0.28 & 0.29 & 0.57 & 0.0387 \\
\hline$\sim \Sigma \mathrm{REE}$ & 47 & 49 & 77 & 97 & 109 & 3.95 \\
\hline $\mathrm{La} / \mathrm{Yb}$ & 8.6 & 8.2 & 9.7 & 8.6 & 5.7 & 1.5 \\
\hline
\end{tabular}




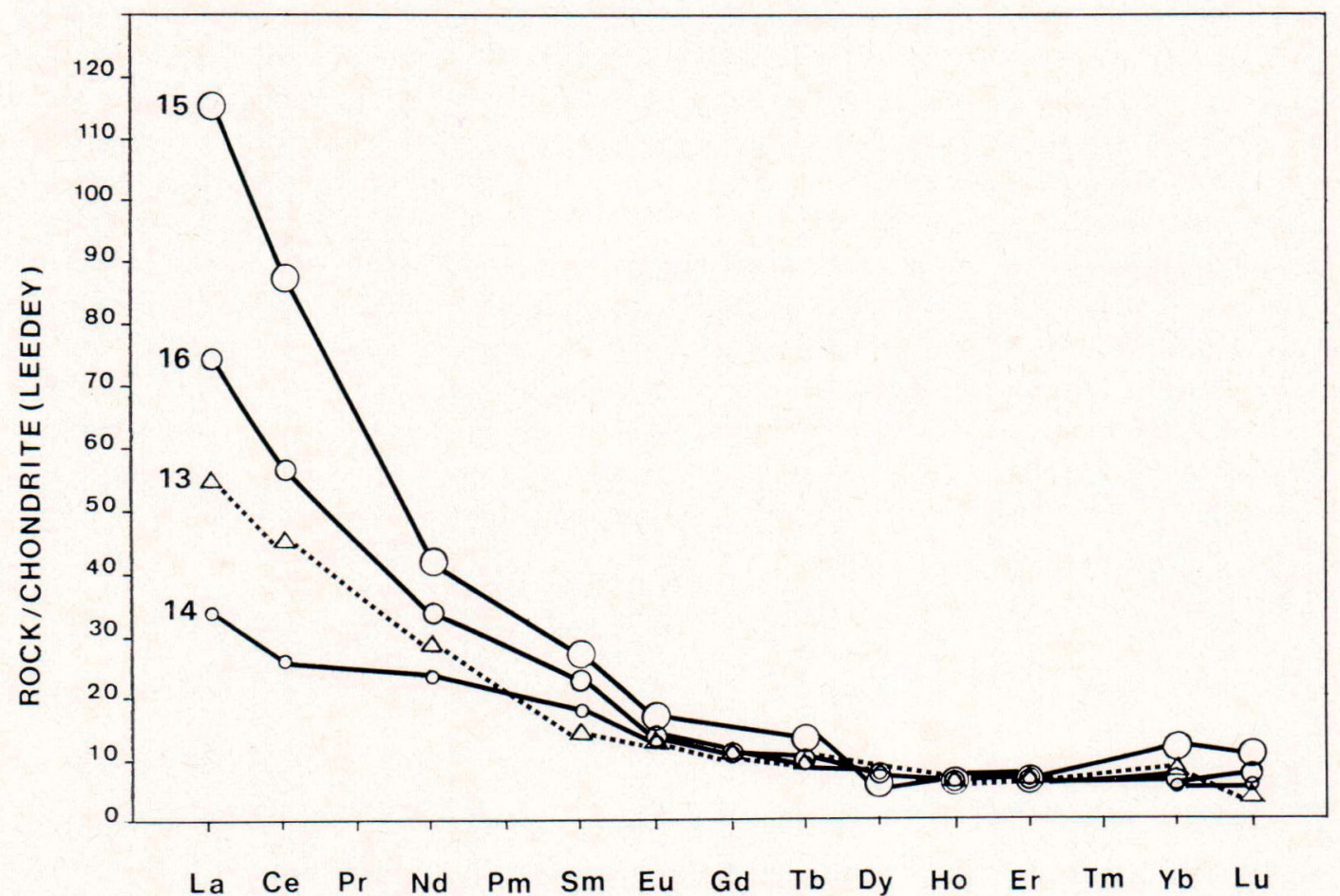

Fig. 3. REE in Precambrian sediments (No. 13), Svecofennian volcanic rocks (No. 14, average of Nos. 1-5), Finnish synorogenic granites (No. 15), and the mean of Nos. 14 and 15 (No. 16).

similar to those found in island arc tholeiitic basalts and in high-temperature peridotites in which light REE are depleted as indicated by normalized graphs ( $c f$. Frey 1969), it would seem that magmas were genereted in the low parts of crust or in the upper mantle (e.g. in the lowvelocity zone) during the early phases of orogeny. As the orogeny advanced, the geosynclinal sediments of the lithosphere were resorbed, and the chemical composition of tholeiitic magmas changed as more and more crustal material was assimilated to that of the calc - alkalic series.

The temporal variation of magmatic rocks similar to those formed during Svecokarelian folding - tholeiitic and calc-alkalic rocks has been observed in island arcs by Kuno (1950, 1959, 1968) and Tilley (1950), and the presence of tholeiitic rocks prior to the eruption of calc - alkalic and alkalic rocks has been emphasized by Baker (1968), Donnelly et al. (1971), Gill (1970) and Jakeš \& White (1969).

From the REE distribution pattern, volcanic and plutonic rocks belonging to the calc-alkalic series seem to have formed through the melting of crustal material, and the REE pattern is thus a fossil remanent of that in basement and sediments ( $c f$. Green \& Ringwood 1968). Under selective anatexis the sediments with their contained REE separated into silica-rich and silicapoor fractions, but the fractions in many places were almost certainly not in magmatic form contemporaneously. The generalized distribution patterns of REE following the separation of the two fractions are similar to those displayed in Fig. 3 (Table 2). The distribution pattern of the average (No. 16) of granites (No. 15) and basic volcanic rocks (No. 14) is similar to that 
found in Precambrian sediments (No. 13). Because no sedimentation basement has been found in the Svecofennian area, it would seem that, over a wide area, it has melted with the geosynclinal sediments to form anatectic magmas (Simonen 1960, p. 95).

The total REE content in magmas formed from sediments through anatexis is higher than that in magmas formed in the mantle, because REE are enriched into the upper crust and into the silica-rich differentiates in it. Every recycling process seems to increase the content of light $\mathrm{REE}$, and the content is accordingly greatest in the latest-formed alkali-rich differentiates. It seems, nevertheless, that REE are enriched only in silicic magmas formed under high-temperature conditions; for low-temperature late differentiates are depleted of them(Koljonen \& Rosenberg1974).

The total content of Eu and heavy REE does not change much during recycling because they can be incorporated into calcic plagioclase (Eu), and into pyroxenes and olivine (Dy- $\mathrm{Lu}$ ) more readily than can the light elements. This difference is indicated by the $\mathrm{La} / \mathrm{Yb}$ ratio, which in the calc-alkalic series is high $(\sim 10)$ and in island arc and abyssal tholeiites low $(\sim 1)$.

\section{REFERENCES}

BAKER, P. E. (1968) Comparative volcanology and petrology of the Atlantic island-arcs. Bull. Volcanol. 32: $189-206$.

Balashov, Yu. A. and Nesterenko, G. V. (1966) Distribution of the rare earths in the traps of the Siberian platform. Geochem. Int. 31: 672-679.

Donnelly, T. W., Rogers, J. J. W., Pushkar, P. and ArmStrong, R. L. (1971) Chemical Evolution of the Igneous Rocks of the Eastern West Indies: an Investigation of the Thorium, Uranium, and Potassium Distributions, and Lead and Strontium Isotopic Ratios. Pp. 151-224 in Caribbean Geophysical, Tectonic, and Petrologic Studies, ed. by T. W. Donnelly. Geol. Soc. Am., Mem. 130.

Eskola, P. (1925) On the petrology of eastern Fennoscandia. I. The mineral development of basic rocks in the Karelian formations. Fennia 45, 19.

EskolA, P. (1963) The Precambrian of Finland. Pp. 145-263 in The Geologic Systems, The Precambrian, I, ed. by K. Rankama. John Wiley \& Sons Inc., New York-London-Sydney.

Frey, F. A. (1969) Rare earth abundances in a hightemperature peridotite intrusion. Geochim. Cosmochim. Acta 33: 1429-1447.

Frey, F. A., Haskin, M. A., Poetz and J. A., Haskin, L. A. (1968) Rare earth abundances in some basic rocks. J. Geophys. Res. 73: 6085-6098.

GaÁl, G. and Rauhamäki, E. (1971) Petrological and structural analysis of the Haukivesi area between Varkaus and Savonlinna, Finland. Geol. Soc. Finland, Bull. 43: 265-337.
GILl, J. B. (1970) Geochemistry of Viti Levu, Fiji and its evolution as an island acr. Contrib. Mineral. Petrol. 27: 179-203.

Green, D. H. (1970) The origin of basaltic and nephelinitic magmas. Trans. Leicester Lit. Philos. Soc. 64: $26-54$.

Green, D. H. and Ringwood, A. E. (1967) The genesis of basaltic magmas. Contr. Mineral. Petrol. 15: 103-190.

Green, D. H. and Ringwood, A. E. (1968) Genesis of the calc-alkaline igneous rock suite. Contrib. Mineral Petrol. 18: 105-162.

Н̈̈rme, M. (1949) On the stratigraphical and structural geology of the Kemi area, northern Finland. Bull. Comm. Géol. Finlande 147.

Härme, M. (1953) [Map of Pre-Quaternary rocks], 2042 Karkkila, Geological Map of Finland, 1: 100000.

Härme, M. (1954) Kallioperäkartan selitys, 2042 Karkkila. English summary: Explanation to the map of rocks. Geological Map of Finland, 1: 100000.

Herrmann, A. G. (1968) Die Verteilung der Lanthaniden in basaltischen Gesteinen. Contrib. Mineral. Petrol. 17: $275-314$.

Herrman, A. G. (1970) Yttrium and lanthanides. In Handbook of Geochemistry 39: 57-71-E1-19, ed. by K. H. Wedepohl. Springer-Verlag, Berlin-Heidelberg-New York.

Jahn, B.-M., Shin, C.-Y. and Murphy, V. R. (1974) Trace element geochemistry of Archean volcanic rocks. Geochim. Cosmochim. Acta 38: 611-627.

JAKEŠ, P. and GiLl, J. (1970) Rare earth elements and 
the island arc tholeiitic series. Earth Planet. Sci. Lett. 9: $17-28$.

JAKEŠ, P. and White, A. J. R. (1969) Structure of the Melanesian Arcs and correlation with distribution of magma types. Tectonophysics 8: $223-236$.

Kaнma, A. (1974) The main metallogenic features of Finland. Geol. Surv. Finland, Bull. 265.

Koljonen, T. (1974) Behavior of selenium in silicic vein rocks and near granitic contacts. Bull. Geol, Soc. Finland 46: 133-139.

Koljonen, T. (1975) Behavior of selenium and sulfur in Svecokarelian sulfide-rich rocks. Bull. Geol. Soc. Finland 47: 25-31.

Koljonen, T. and Rosenberg, R. J. (1974) Rare earth elements in granitic rocks Lithos 7: 249-261.

Kuno, H. (1950) Petrology of the Hakone Volcano and adjancent areas, Japan. Bull. Geol. Soc. Am. 61: $957-1020$.

Kuno, H. (1959) Origin of Cenozoic petrographic provinces of Japan and surrounding areas. Bull. Volcanol. 20: $37-76$.

Kuno, H. (1968) Origin of andesite and its bearing on the island arc structure. Bull. Volcanol. 32: 141176.

LAajokr, K. (1973) On the geology of the South Puolanka area, Finland. Geol. Surv. Finland, Bull. 263.

LAAJOKI, K. (1975) Rare-earth elements in Precambrian iron formation in Väyrylänkylä, South Puolanka area, Finland. Geol. Soc. Finland, Bull. 47: 91-105.

Laitala, M. (1964) [Map of the Pre-Quaternary rocks], 3021, Porvoo. Suomen Geologinen Kartta, 1: 100000.

LaitalA, M. (1965) [Map of the Pre-Quaternary rocks], 3012, Pellinki. Suomen Geologinen kartta, 1: 100000.

Laitala, M. (1973) On the Precambrian bedrock and its structure in the Pellinge region, South Finland. Geol. Surv. Finland, Bull. 264.

Masuda, A. and Matsui, Y. (1966) The difference in lanthanide abundance pattern between the crust and the chondrite and its possible meaning to the genesis of crust and mantle. Geochim. Cosmochim. Acta 30: 239-250.

Masuda, A., Nakamura, N. and Tanaka, T. (1973) Fine structures of mutually normalized rare-earth patterns of chondrites. Geochim. Cosmochim. Acta 37:239-248.

MeriläInen, K. (1961) Albite diabases and albitites in Enontekiö and Kittilä, Finland. Bull. Comm. Géol. Finlande 195.

Miknola, A. (1949) On the geology of the area North of the Gulf of Bothnia. Bull. Comm. Géol. Finlande 146.

MiккоцA, A. and Ninn, H. (1968) Structural position of orebearing areas in Finland. Bull. Geol. Soc. Finland 40: $17-33$.

Nakamura, N. and Masuda, A. (1971) Rare earth elements in abyssal basalts and plateau basalts. Nature, Phys. Sci. 233: $130-131$.

NyKänEN, O. (1971) On the Karelides in the Tohmajärvi area, eastern Finland. Bull. Geol. Soc. Finland 43: 93-108.

Pirrainen, T. (1974) Spiliittinen magmatismi ja siihen liittyvä malminmuodostus karjalaisella liuskevyöhykkeellä Suomessa. Summary: Spilitic igneous activity and ore genesis in the Karelian schist zone in Finland. Geologi 26: 93-98.

Pirrainen, T. and Rouhunkoski, P. (1974) General Features of the Spilitic Rocks in Finland. Pp. 191-205 in Spilites and Spilitic Rocks ed. by G. G. Amstutz. Springer-Verlag, Berlin-Heidelberg-New York.

Pirspanen, R. (1972) On the spilitic rocks of the Karelidic belt in western Kuusamo, northeastern Finland. Acta Univ. Ouluensis, Ser. A, Geologica 2.

Rosenber G, R. J. (1972) Instrumental activation analysis of Lunar samples. Suomen. Kemistilehti B45: 399404.

Rosenberg, R. J. and Wink, H. B. (1971) Instrumental activation analysis of 11 lanthanide elements in Apollo 12 Lunar samples. Radiochim. Radioanal. Lett. 6: $45-55$.

Sahama, Th. G. (1945) Spurenelemente der Gesteine im südlichen Finnisch-Lappland. Bull. Comm. Géol. Finlande 135.

Schilling, J.-G. and Winchester, J. W. (1969) Rare earth contribution to the origin of Hawaiian lavas. Contrib. Mineral. Petrol. 23: 27-37.

Schmitr, R. A., Smith, R. H. and Olehy, D. A. (1964) Rare-earth, yttrium and scandium abundances in meteoritic and terrestrial matter -II. Geochim. Cosmochim. Acta 28: 67-85.

Sederholm, J. J. (1897) Über eine archäische Sedimentformation in südwestlichen Finland und ihre Bedeutung für die Erklärung der Entstehungsweise des Grundgebirges. Bull. Comm. Géol. Finlande 6 .

Sederholm, J. J. (1907) Om granit och gneis, deras uppkomst, uppträde och utbredning inom urberget i Fennoskandia. Bull. Comm. Géol. Finlande 23.

Sederholm, J. J. (1923) On migmatites and associated pre-Cambrian rocks of southwestern Finland. Part I. The Pellinge region. Bull. Comm. Géol. Finlande 58.

Sederholm, J. J. (1926) On migmatites and associated pre-Cambrian rocks of southwestern Finland. Part II. The region around the Barösundsfjärd W. of Helsingfors and neighbouring areas. Bull. Comm. Géol. Finlande 77.

Sederholm, J. J. (1934) On migmatites and associated pre-Cambrian rocks of Southwestern Finland. Part III. The Alland Islands. Bull. Comm. Géol. Finlande 107. 
SeItSAARI, J. (1951) The schist belt Northeast of Tampere in Finland. Bull. Comm. Géol. Finlande 153.

Simonen, A. (1948) On the petrochemistry of the infracrustal rocks in the Svecofennidic territory of southwestern Finland. Bull. Comm. Géol. Finlande 141.

Simonen, A. (1953) Stratigraphy and sedimentation of the Svecofennidic, early Archean supracrustal rocks in southwestern Finland. Bull. Comm. Géol. Finlande 160.

Srmonen, A. (1960 a) Pre-Quaternary rocks in Finland. Bull. Comm. Géol. Finlande 191.

Simonen, A. (1960 b) Plutonic rocks of the Svecofennides in Finland. Bull. Comm. Géol. Finlande 189.

TenholA, M. (1971) Hyvinkään gabroalueen petrologiasta. Unpubl. Manuscr., Arch. Dep. Geol. Miner., Univ. Helsinki.

Tilley, C. E. (1950) Some aspects of magmatic evolution. Q. J. Geol. Soc. Lond. 106: 37-61.
Tuomnen, H. V. (1958) Origin of the Orijärvi granodiorite, Finland, by metamorphic differentiation. Bull. Geol. Soc. Am. 69: 1654.

Tuominen, H. V. (1966) Structural control of composition in the Orijärvi granodiorite. C. R. Soc. Géol. Finlande 37: 311-329.

Tuominen, H. V., Aarnisalo, J. and Söderholm, B. (1973) Tectonic patterns in the central Baltic Shield. Bull. Geol. Soc. Finland 45: 205-217.

VäYRYNEN, H. (1928) Geologische und petrographishe Untersuchungen im Kainuugebiete. Bull. Comm. Géol. Finlande 78 .

Wildeman, T. R. and Haskin, L. A. (1973) Rare earths in Precambrian sediments. Geochim. Cosmochim. Acta 37: 419-438.

Manuscript received, 17 February, 1975. 